\title{
Air and Seawater Quality Assessment Around Selected Area in Panjang Port Lampung Region
}

\author{
Agus Salim ${ }^{1, *}$, Nunung Isnaini Dwi Ningsih ${ }^{2, * *}$, A. Sulaiman ${ }^{3, * * *}$ \\ ${ }^{1}$ Biology Department, ${ }^{2}$ Physic Department, Faculty of Science and Technology, UIN Syarif Hidayatullah, \\ ${ }^{3}$ Geostech Laboratory, Badan Pengkajian dan Penerapan Teknologi, Jakarta, Indonesia \\ Email: agus_salim@uinjkt.ac.id*,nunung_isnaini@uinjkt.ac.id**, albertus.sulaiman@bppt.go.id***
}

\begin{abstract}
The port area is a diverse business district, both industry and other activities. Even though it is positioned far from residential areas, the impact of its activities indirectly still reaches the surrounding community. The environmental conditions of the port area need to be controlled routinely so that their management does not violate applicable regulations. Environmental management is needed so that risks arising from all activities can be controlled. Panjang Port as one of the well-developed fuel storage terminals as part of the Pelindo II region. This study has been designed to assess air quality and seawater quality around Panjang Port, Bandar Lampung, Indonesia. Several air quality parameters and marine water quality parameters were monitored from 2011 to 2013 . The air quality sampling conducted in the fuel storage tank area and chemicals as well as supporting facilities. The air quality parameters are $\mathrm{SO} 2, \mathrm{NO} 2, \mathrm{O} 3, \mathrm{CO}, \mathrm{H} 2 \mathrm{~S}$, and dust. The results of data analysis showed several air quality parameters such as $\mathrm{SO} 2, \mathrm{NO} 2, \mathrm{O} 3$, dust, $\mathrm{H} 2 \mathrm{~S}$, and $\mathrm{NH} 3$ are below the threshold of minimum quality standard. Only the CO parameter tends to increase semester to semester. The seawater quality parameters include physical, chemical, and biological quality. Almost the physical quality parameters are below the quality standard, thus the chemical quality too, except the $\mathrm{pH}$ and TSS tends to higher than a quality standard. In general, these studies on air quality and seawater quality at the Panjang Port have been carried out well and the results show that the environmental conditions for the Panjang Port area are still quite good, only it is recommended to add a green area around the site.
\end{abstract}

Keywords: Air Quality, Seawater Quality, Management Environmental

\section{INTRODUCTION}

The port area is a diverse business district, both industrial and other activities. Although positioned far from the settlement, the impact of its activities indirectly still reaches the surrounding community. Environmental conditions in the port area need to be controlled routinely so that management does not violate applicable regulations. Research on this has been carried out in Lahore and it has been concluded that increasing levels of no, co, and tsp are prevalent in the main regions of Lahore. This has an impact on the general public who suffer as a result of air pollution and noise, and long-term exposure which is a major risk for the population due to increased traffic loads and uncontrolled emissions. This study provides a recommendation that it exists an urgent need to adopt an air quality management strategy to improve the quality of downtown air. Besides, there is a need for a public awareness program regarding the use of public transportation systems, strict implementation of the issuance of appropriate certificates for vehicles, and the need to promote the use of cleaner fuels necessary to reduce vehicle emissions (Almas Hamid, A., Et.al, 2019). A study on ambient water quality and noise levels around selected oil and gas facilities in Nigeria has carried out. The study concluded that the oil and gas facilities negatively affected the water environment of the host communities. Long-term health effects due to continuous daily exposure of the host communities were envisaged. Therefore, epidemiological health impact assessments conducted in all host communities in determining the level of impact on the people (J. N. Ugbebor, J.N., and Yorkor, B, 2018). Analysis of seaport and dock pollution in the state of the river, Nigeria has been carried out and concluded that the activities in the port of Onne are within acceptable limits. It was also observed from questionnaires distributed to respondents with larger populations in the ports of Onne, Okrika and Port Harcourt which showed that they were aware of the sources and effects of environmental pollution from each port. The fact that sea pollution will greatly affect coastal resources of cities, countries, and nations, must be avoided. This can be done by complying with the rules and arrangements made by national and international organizations that care about the environment, especially the maritime environment. Industries around ports or docks can also contribute to the pollution of the marine environment by releasing hazardous chemicals into the sea (Nitonye, S., Uyi, O, 2018).

Regions Pelindo (Pelabuhan Indonesia) II Panjang Port area as well as elsewhere in Indonesia, is one area that is already well developed. Various businesses are growing in the region to support national development. However, such development must comply with the government program, a program of sustainable development and environmentally sound. Although the 
impact of the existing and relatively less important impact, if not done properly management, the impact appears to be causing a negative image. Referring to the environmental documents that the existence of this tank storage facility is intended to meet the needs of external companies by providing petroleum products and other chemicals to the island of Java in particular and Indonesia in general. Mechanism workflow implementation activities of UKL surgery performed on stage or stages of the ongoing activities. Where in this Operation Phase activities taking place, that the activities of loading and unloading and stockpiling of fuel and other chemicals. This is operation has lasted approximately four years since the beginning of 2007 until now has been awakened diverse environment protection facilities including the system drains, a protective wall (bund wall), oil catcher, facilities firefighters and the surface. Implementation of the operating phase of activities produces significant impacts on the surrounding environment, either a positive or negative impact. The study was done 3 years (6 semesters) needs is underway to see how far the effectiveness of management activities undertaken by the company concerned. The indicator is whether the components of environmental parameters examined or assessed are under raw environmental quality set by the government or vice versa. In this regard, the research activity focuses on the assessment of air quality and seawater quality around the selected area in Panjang Port Lampung Region of the semester to semester each year. The results of this study became the basis for management activities to be undertaken in the next year refers to the statistical trend parameter quality environment observation results were assessed.

\section{MATERIALS AND METHODS}

\section{Study area}

This study area is in Panjang Port, Panjang District, Bandar Lampung, Indonesia and this is an area of PT. Pelabuhan Indonesia II. This research focuses on the monitoring of air quality and seawater quality in 2011 2013.

\footnotetext{
Material and methods

This research site was in Pelabuhan Panjang, Pelindo II area in Bandar Lampung, Indonesia. Data on air and seawater quality sampling twice a year in the period 2011 - 2013. The environmental assessment for air quality study conducted at two points, ie one point outside the project area activities, and 1 point in the fuel storage tank area and chemicals as well as supporting facilities. The study was conducted at two locations at the point of the waters surrounding the activity site (Pier) precisely at the point AU.7 = Panjang
}

I (0606'10,6 "LS; 106 $54^{\prime} 14,5^{\prime \prime}$ BT) and dot AU.8 = Panjang II (060'ㄴ, 13,8 "LS; 10654'19,3" BT).

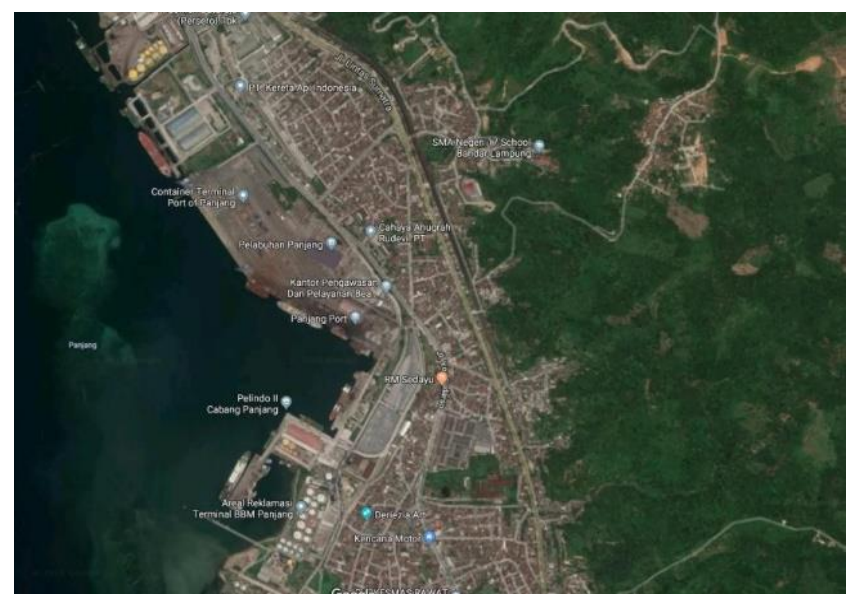

Figure 1. Location of Panjang Port, Panjang District, Bandar Lampung.

The air quality parameters to be studied are $\mathrm{SO}_{2}$, $\mathrm{NO}_{2}, \mathrm{O}_{3}, \mathrm{CO}, \mathrm{H}_{2} \mathrm{~S}$, and dust. Seawater parameters to be studied include physical, chemical and biological parameters. Therefore, research on seawater was carried out in the area of PT. (Persero) Pelabuhan Indonesia II and Panjang Regency. Data analysis using AAS instruments in the laboratory, then statistical analysis is used to describe the results of data analysis. Benchmarks have an impact on ambient air quality standards referring to the Decree of the Governor of Lampung No. 551 of 2001 concerning Ambient Air Quality Standards and Raw Noise Levels.

\section{Procedures}

The sampling method is done by taking a sample of seawater - in the form of materials chemicals used to sample the water is $\mathrm{H}_{2} \mathrm{SO}_{4}, \mathrm{HNO}_{3}$ solution, distilled water for washing. And tools such as 1) Kammerer water sampler or glass bottle with a capacity of 0.75 liters of mines and cover plastic sample bottles or polyethylene and glasses with a capacity of at least $500 \mathrm{ml}$ which is used for the collection of sample water. 2) Pipette drops of $0.02 \mathrm{ml}$ and 3) BOD bottle of dark and light, a capacity of $300 \mathrm{ml}$ for each sampling point.

\section{Data analysis}

The statistical descriptive was used to describing the result of data analysis. The results of air quality and seawater quality in the study area are presented in Figures 1, 2, 3, and 4.

\section{RESULT AND DISCUSSION}

\section{Results}

There are seven air quality parameters assessed. These parameters will check for compliance with ambient air quality standards as stipulated in the Decree of the 
Governor of Lampung No. 551 of 2001 about Ambient Air Quality Standards and Raw Noise Levels. The sampling point is outside the project area activity and 1 point is in the fuel and chemical storage tank area and supporting facilities. Table 1 , presents data on air quality parameters, and Figure 1, is a graph of air quality concentration every semester in the 2011-2013 period.

Table 1. Data of air quality parameters in 2011-2013

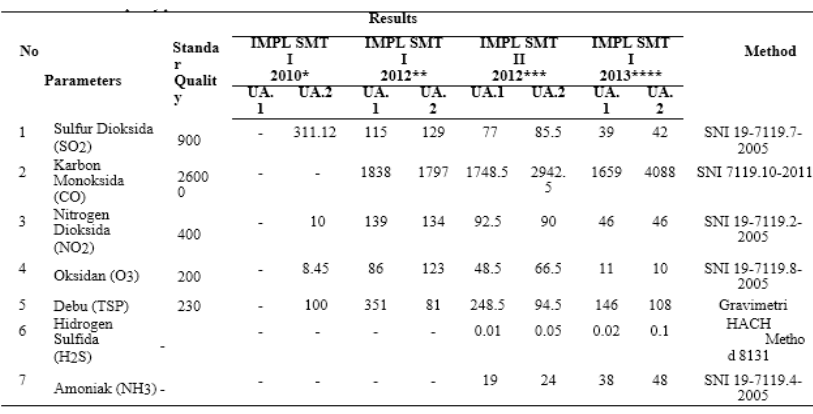

Based on table 1, it appears that the results of the analysis of 7 air quality parameters are almost all below the standards stipulated in the Decree of the Governor of Lampung 551 in 2001 . Only the CO parameters in the second semester of 2012 and 2013 exceeded the standard limits. To clarify, the following are the results of the analysis of each parameter.

\section{$\mathrm{SO}_{2}$ Parameter}

Measurement of air quality for $\mathrm{SO}_{2}$ limits in the study sites showed that the measurement results of ambient air quality in the two points is under the minimum threshold is $32 \mathrm{ug} / \mathrm{m}^{3}$ for the front of the warehouse and $131 \mathrm{ug} / \mathrm{m}^{3}$ for the back of the barn with a minimum limit $\mathrm{SO}_{2}$ concentration is based on the quality standard is $900 \mathrm{mg} / \mathrm{Nm}^{3}$ (Decree of the Governor of Lampung 551 in 2001). These results together with the measurement at the previous implementations that do not pass the threshold were $136 \mathrm{mg} / \mathrm{Nm}^{3}$ (Implementation II 2012). From the results of $\mathrm{SO}_{2}$ measurements in the field, it can be stated that the environmental conditions PT.AKR Corporindo, Tbk Panjang still good.

\section{$\mathrm{NO}_{2}$ Parameter}

Value measurement of $\mathrm{NO}_{2}$ at the point of observation showed that the measurement results the ambient air quality in the two points is under the minimum threshold is $114 \mathrm{ug} / \mathrm{m} 3$ for the front of the warehouse and $115 \mathrm{ug} / \mathrm{m}^{3}$ for the back of the barn with a minimum threshold concentration of $\mathrm{NO}_{2}$ is based on the quality standard is $400 \mathrm{mg} / \mathrm{Nm} 3$ (Decree of the Governor of Lampung 551 in 2001). As with previous measurements, ie $109 \mathrm{ug} / \mathrm{m}^{3}$ (SMT I Year 2012) and $105 \mathrm{ug} / \mathrm{m}^{3}$ (SMT II in 2012) $\mathrm{NO}_{2}$ concentration in the sample location is below the threshold value. Although it should still watch out because its value is increasing from year to year.

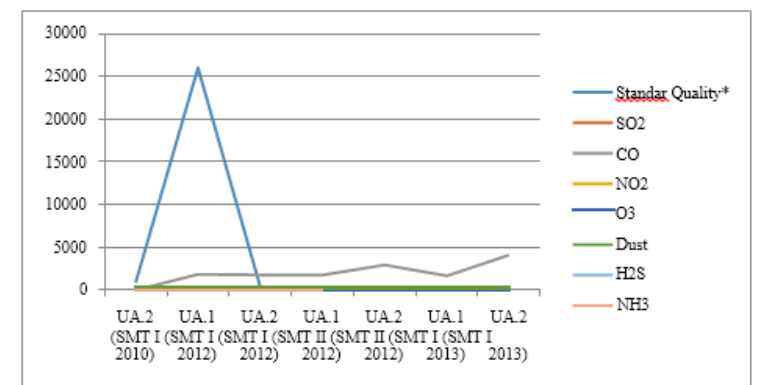

Figure 2. Concentrations of air quality every semester in periods of 2011 2013.

\section{$\mathrm{O}_{3}$ Parameters}

Value measurement of $\mathrm{O}_{3}$ at the point of observation showed that the results of measurements of the ambient air quality in the two points is under the minimum threshold are $5 \mathrm{ug} / \mathrm{m}^{3}$ for the front of the warehouse and $3 \mathrm{ug} / \mathrm{m}^{3}$ for the back of the barn with a minimum threshold concentration of $\mathrm{O}_{3}$ based quality standard is $200 \mathrm{mg} / \mathrm{Nm}^{3}$ (Decree of the Governor of Lampung 551 in 2001). When compared with previous measurements of $20 \mathrm{ug} / \mathrm{m}^{3}$ (2011) and $15 \mathrm{ug} / \mathrm{m}^{3}$ (2012) looks at lowering concentrations of $\mathrm{O}_{3}$ from 2011 to 2013. It shows good results for the environment.

\section{Dust Parameter}

Value parameter measurements of dust at the point of observation showed that the results of measurements of the ambient air quality in the two points are under the minimum threshold of $70 \mathrm{ug} / \mathrm{m}^{3}$ for the front of the warehouse and $58 \mathrm{ug} / \mathrm{m}^{3}$ to the rear of the barn with a minimum limit concentration of dust is based on the quality standard is $230 \mathrm{mg} / \mathrm{Nm}^{3}$ (Decree of the Governor of Lampung 551 in 2001). When seen from the results of the implementation of the previous (2012) is $84 \mathrm{mg} / \mathrm{Nm}^{3}$, dust concentration decreases which indicate improvements in the quality of the environment.

\section{CO Parameter}

Value measurement of $\mathrm{CO}$ at the observation point of activities shows that the results of measurements of the ambient air quality in the two points is under the minimum threshold is $1430 \mathrm{ug} / \mathrm{m}^{3}$ for the front of the warehouse and $1393 \mathrm{ug} / \mathrm{m}^{3}$ for the back of the warehouse with minimum concentration of $\mathrm{SO}_{2}$ is based on the quality standard is $26,000 \mathrm{mg} / \mathrm{Nm}^{3}$ (Decree of the Governor of Lampung 551 in 2001).

\section{$\mathrm{H}_{2} \mathrm{~S}$ Parameter}

Parameter measurement values reduced sulfur $\left(\mathrm{H}_{2} \mathrm{~S}\right)$ at the point of observation showed that the measurement results of ambient air quality in the two points are under the minimum threshold of $<0.01 \mathrm{mg} / \mathrm{m}^{3}$ for the front and rear warehouse (Decree of the Governor of Lampung 551 in 2001). This shows that the environment still has good air quality. 


\section{$\mathrm{NH}_{3}$ Parameter}

Parameter measurement values Ammonia (NH3) at the point of observation showed that the measurement results of ambient air quality in the two points are under the minimum threshold is $3 \mathrm{ug} / \mathrm{m}^{3}$ for the front and rear warehouse (Decree of the Governor of Lampung 551 in 2001).

The following analysis of seawater quality in the study area. There are 6 physical parameters, 7 chemicals, and one biological parameter of the quality of seawater has been assessed. These parameters correlate with ambient air quality standards as stipulated in the Decree of the Governor of Lampung No. 551 of 2001 concerning Ambient Air Quality Standards and Raw Noise Levels. The sampling point is outside the project area activity and one point is in the fuel and chemical storage tank area and supporting facilities. Table 1, presents data on air quality parameters, and Figure 1, illustrates the concentration of air quality each semester in the 2011-2013 period.

Table 2. Data of sea water quality for physical parameters in 2011-2013.

\begin{tabular}{|c|c|c|c|c|c|c|c|c|c|c|c|c|}
\hline \multirow{2}{*}{ No } & \multirow{2}{*}{ Parameters } & \multirow{2}{*}{ Unit } & \multirow{2}{*}{$\begin{array}{l}\text { Standar } \\
\text { Quality }\end{array}$} & \multicolumn{2}{|c|}{$\begin{array}{l}\text { IMPL SMT I } \\
2010^{* *}\end{array}$} & \multicolumn{2}{|c|}{$\begin{array}{c}\text { IMPL SMT I } \\
2012 * * *\end{array}$} & \multicolumn{2}{|c|}{$\begin{array}{c}\text { IMPL SMT II } \\
2012 * * * *\end{array}$} & \multicolumn{2}{|c|}{$\begin{array}{c}\text { IMPL SMT I } \\
2013 * * * * *\end{array}$} & \multirow{2}{*}{ Metode } \\
\hline & & & & AU.4 & AU.5 & AU.4 & AU.5 & AU.4 & AU.5 & AU.4 & AU.5 & \\
\hline 1 & Turbidity & Meter & - & - & - & 4 & 4 & 2.5 & 3 & 1 & 2 & \\
\hline 2 & Smell & - & No Smell & - & - & No Smell & No Smell & No Smell & No Smell & No Smell & No Smell & Organoleptik \\
\hline 3 & TSS & $\mathrm{mg} / \mathrm{L}$ & 80 & 20 & 8 & 178 & 118 & 160 & 127 & 142 & 136 & SNI 06-6989-3-2004 \\
\hline 4 & Waste & - & Nihil & & & Nihil & Nihil & Nihil & Nihil & Nihil & Nihil & Visual \\
\hline 5 & $\begin{array}{l}\text { Temperatur } \\
\text { (insitu) }\end{array}$ & ${ }^{\mathrm{o}} \mathrm{C}$ & Natural & 32.3 & 33.4 & 30.7 & 31 & 31 & 31.2 & 31.3 & 31.4 & SNI 06-6989.23.2005 \\
\hline 6 & Oil Layers & - & Nihil & $<1$ & $<1$ & Nihil & Nihil & Nihil & Nihil & Nihil & Nihil & Visual \\
\hline
\end{tabular}

Based on the analysis of seawater physical quality that can be seen in Table 2, that the Turbidity, Odor, TSS, Waste, Temperature, and oil seams parameters tend to be below the seawater physical quality standard, based on KepMenLH 51/2004 Appendix 1 for Water Ports. Meanwhile, the chemical parameters and one biological parameter are shown in the graph in Figure 2.

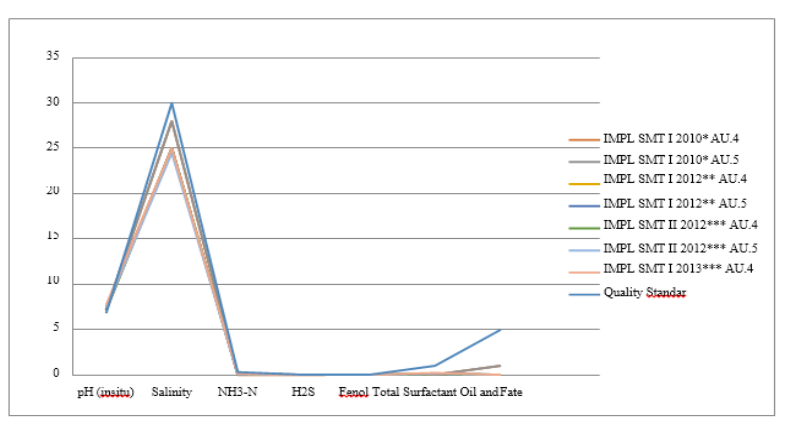

Figure 3. Concentrations of seawater quality every semester in periods of 2011-2013

The results of the analysis of chemical quality of the seawater at the point measured that $\mathrm{pH}$ (insitu), $\mathrm{NH}_{3}-\mathrm{N}, \mathrm{H}_{2} \mathrm{~S}$, total compound of Fenol, and oil and fate tend to be below the quality standard chemical quality of the seawater in the period IMPL SMT I in 2013, based on Ministry of Environment Decree 51/2004, Appendix 1 for Water Port. While the period IMPL SMT I Year 2013 chemical quality $\mathrm{pH}$ is above the standard quality. In contrast to the chemical quality of the analytical results tend $\mathrm{pH}$ above quality standards seawater chemistry, IMPL SMT I 2009, I 2012 IMPL SMT and SMT IMPL II in 2012, this is because of the contaminated ammonia or anionic surfactant (detergent). From the measurement results SMT 1 Year 2013 all chemical parameters is below the quality standard chemical quality of the seawater, based Ministry of Environment Decree 51/2004 Appendix 1 for Water Port. Biological quality analysis is carried out on surface water and the results show that at the point of measurement that E. Coli and Coliform are above the quality standards in the IMPL SMT period 12009 for IMPL I. While in IMPL II 2013 the value has dropped and is within the quality standards permitted by Ministry of Environment Decree 51/2004, Appendix 1 for Water Ports. Rise and fall of the parameter values of E. coli and coliform because there is a possibility of leakage of waste to pollute the surface

\section{Discussion}

A study of air quality and seawater quality assessments around the selected area in the Panjang port has carried out. The air quality almost below on quality standard. The $\mathrm{SO}_{2}$ concentration tends to decrease meanwhile, the $\mathrm{CO}$ concentrations tend to increase from semester to semester. The value of $\mathrm{NO}_{2}$ concentration is high in SMTR I 2012 at both observation points (UA.1 and UA.2) but still below the quality standard value, and the $\mathrm{O}_{3}$ concentration is far below the quality standard for 6 semesters. For the dust tends to fluctuate with values ranging from 80-150, tend to very high in SMTR I 2012 to the point UA. 
The evaluation results for seawater parameters have some trends in the parameters of $\mathrm{pH}$, TSS, and Oil and Fat show that $\mathrm{pH}$ and TSS parameters for the whole period tend to increase and exceed the quality standard. But for the parameters of oil and fat as pollution indicators, it is still below the specified environmental standards. This shows that the water released from the oil catching facility has gone through a gradual and good condition of waste treatment.

In general, these studies on air quality and seawater quality at the Panjang port have been carried out well and the results show that the environmental conditions for the Panjang port area are still quite good, only it is recommended to add a green area around the site.

\section{CONCLUSION}

This study area is in Panjang Port, Panjang District, Bandar Lampung, Indonesia and this is an area of PT. Pelabuhan Indonesia II. This research focuses on the monitoring of air quality and seawater quality in $2011-$ 2013. In general, these studies on air quality and seawater quality at the Panjang port have been carried out well and the results show that the environmental conditions for the Panjang port area are still quite good, only it is recommended to add a green area around the site.

\section{ACKNOWLEDGEMENTS}

This research funded by AKR Corporindo TBK, Company.

\section{REFERENCES}

Almas Hamid, A., et.al. (2019). Ambient Air Quality \& Noise Level Monitoring of Different Areas of Lahore (Pakistan) and Its Health Impacts. Pol. J. Environ. Stud. Vol. 28, No. 2, 623629.
Anonymous, 2007. UKL-UPL Kegiatan Stasiun Pengisian Bahan Bakar Umum (SPBU) Shell Jl. Pramuka Raya No. 140-141 RT 014/ RW 05, Kelurahan Rawasari, Kecamatan Cempaka Putih, Kotamadya Jakarta Pusat dari BPLHD Provinsi DKI Jakarta, Jakarta. PT. Shell Indonesia.

Djajadiningrat, S.T., dan Amir, H.H. 1991. Penilaian Secara Cepat Sumber-sumber Pencemar Air, Tanah dan Udara. Gadjah Mada University Press, Yogyakarta.

Darmono. 1995. Logam dalam Sistem Biologi Makhluk Hidup. Penerbit Universitas Indonesia (UI-Press), Jakarta.

Effendi, H. 2003. Telaah Kualitas Air Bagi Pengelolaan Sumber Daya dan Lingkungan Perairan. Penerbit Kanisius, Yogyakarta.

J. N. Ugbebor, J.N., and Yorkor, B. (2018). Assessment of Ambient Air Quality and Noise Levels around Selected Oil and Gas Facilities in Nigeria. Journal of Scientific Research \& Reports, 1-11.

Magrab, Edward, B. 1975. Environmental Noise Control. John Wiley \& Sons. New York.

Nitonye, S., Uyi, O. (2018). Analysis of Marine Pollution of Ports and Jetties in Rivers State, Nigeria. Open Journal of Marine Science, 114-135.

PT Shell Indonesia. 2007. UKL-UPL Kegiatan SPBU J1. Pramuka Raya 140-141, Kelurahan Rawasari, Kecamatan Cempaka Putih, Kotamadya Jakarta Pusat, Jakarta.

Riyadi, S.A.L. 1982. Pencemaran Udara. Penerbit Usaha Nasional, Surabaya.

Rai MK, Carpinella C. 2006. Naturally Occurring Bioactive Compounds. Elsevier, Amsterdam.

Stern, A.C., R.W. Boubel, D.B. Turner, and D.L. Fox. 1984. Fundamental of Air pollution. Second ed. Academic Press Inc. Orlando-Florida.

Wahi, S.K., A.K. Agnihotri, and J.S. Sharma (editors). 1992. Environmenal Management in Petroleum Industry. Wiley Eastern Limited, New Delhi. APHA. 1989. Standard Methods for the Examination of Water and Waste-water. APHA. AWWA and WPCP. $17^{\text {th }}$ ed. Washington DC. 
THIS PAGE INTENTIONALLY LEFT BLANK 